NBER WORKING PAPER SERIES

\title{
A MODEL OF DIFFUSION IN THE PRODUCTION \\ OF AN INNOVATION
}

Michael Gort

Akira Konakayama

Working Paper No. 297
NATIONAL BUREAU OF ECONOMIC RESEARCH 1050 Massachusetts Avenue
Cambridge MA 02138

November 1978

The research reported here is part of the NBER's research program on Productivity. Any opinions expressed are those of the authors and not those of the National Bureau of Economic Research. The paper was prepared with the help of a grant from the National Science Foundation (Grant No. RDA 73-04240). 
A Model of Diffusion in the Production of an Innovation

Summary

Th1s paper is an attempt to explain diffusion in the production of an Innovation. Diffusion in production is defined as the increase in number of producers, or net entry, in the market for a new product. It is to be distinguished from the more familiar problem in the literature on technical change, namely, the diffusion among producers in the use of new products and, hence, of changes in production processes for "old" products (or services). The empirical resulta confirm that a aimple model - simple in terms of number of vartables - is sufficlent to explain most of diffusion in the production of an innovation. The principal varlable that explains diffusion of entry is the demonstration effect. The principal variable that retards entry is the accumulated experience and goodwill of existing firms. A limiting force 18 the population of potential entrants. None of these variables appears to lend itself readily to influence by public policy.

The first stage in diffusion -- the interval from first comercial introduction of the product to entry by competitors -- varies greatly in duration. Institutional variables, Including public pollcy, may have a greater impact on the length of this first stage, which is not covered by this study, than on the diffusion process in the periods examined in this paper.

Michael Gort and Akira Konakayama Department of Economics State University of New York at Buffalo John Lord O'Brian Hall, North Campus Buffalo, New York 14260

(716) $636-2121,2122$ 
Th1s paper 18 an attempt to expla1n the process of diffusion in the production of an Innovation. Diffusion in production is defined as the Increase In number of producers, or net entry, In the market for a new product. It is to be distingulshed from the more famlliar problem in the literature on technical change, namely, the diffusion among producers in the use of new products and, hence, of changes in production processes for "old" products (or services). In an earlier paper, Gort and Klepper" showed that a typical "diffusion in production" process Involves a number of stages. Phase I encompasses the Interval In which the original producers of a new product remain without competitors in the market. Phase II 18 the Interval from the "take-off" point of net entry to the the that net entry decelerates drastically. Phase III 18 the ensulng perlod of 10 or zero net entry and Phase IV 1s the subsequent period of negative net entry. Phase $V$ represents the new equilibrium in the number of producers that colncides with the maturity of the product market and continues until some new fundamental disturbance generates a change in market structure. The present study focuges on the pertod from roughly the beginning of stage II until the peak in number of producers 18 reached sometime in stage III. It does not denl wth the subsequent development of what may be considered a mature market, Including the characteristic interval in which the number of producers declines. Theory

For given expected prices and demand, the diviaion of the market between existing firms and new entrants depends on $V$, a vector of observed attributes of the population of potential entrants, and G, a vector of observed attributes of the population of earlier entrants (and now exieting f1rms) in the market. The average probability of entry in time $t$ for the population of potential entrants can be written as:

$$
P_{t}=P_{t}\left(G_{t}, V_{t}\right)
$$

\footnotetext{
1M. Gort and S. Klepper, "Time Paths In the DIffusion of Product Innovations," State Univerelty of New York at Buffalo, Economlcs Department, D1scussion Paper No. 444.
} 
We assume that the unobserved attributes of Individual firms (which include such facotrs as the personalities and biases of managers, chance perceptions of alternative opportunities, differences in risk aversion, etc.) are randomly distributed among firms with a common set of observed characteristics. 1

Apart from the attributes of existing firms and potential entrants, the expected returns to new entrants, discounted for risk, (and, hence, the entry rate) w111 depend upon a) the percelved risks associated with entry and b) the expected profit margin for the most efficlent producers. Assuming a market without entry barriers and an equilibrium price at which output is greater than zero, the expected profit margin will depend upon the extent of any transitory disequilibrium between supply and demend. To be sure, profit margins will also depend upon entry barriers-that 18, monopoly power. But higher entry barriers cannot, by definition, ralse the rate of net entry. Consequently, an excess of actual over "normal" competitive rates of return will ralse entry only to the extent that such returns artec from dieequilibrium. ${ }^{2}$

Assumg an absence of entry barrlers, we have Indicated that antry will depend upon percelved risks, disequilibrium induced deviations between actual and "normal" competitive profit margins, and the attributes (mainly costs) of exleting firms and of the population of potential entrants. Before apecifying

1For a given probability of cholce taking account of the relevant variables, the observed gross number of entrants to a random number obeying a binomial distribut10n. Th1s is becauge each firm faces a blangy cholce of entry or non-entry. The ane principle applies to grose exits.

${ }^{2}$ Some entry barriers are themselves transitory in the sense that they generate incentives that lead to their destruction. Such barriers can also be classified as sources of transitory disequilibrla. 
the relevant (and empirically measurable) variables that control each of these elements, our model must be developed further with respect to the two components that generate the net entry rate, namely, gross entry and grosi exit.

Let $\bar{N}$ denote the population of potential entrants in the market for a new product. At $t 1 m e t$, the number of potential entrants w1ll then be $\bar{N}-n_{t-1}$ where $\mathbf{n}_{t-1} 18$ the number that have already entered--that 18, the number of producers at $t-1$. The number of expected entrants at time $t$ is therefore:

$$
P_{t}=P_{t} \times\left(\overline{\mathbf{N}}-\mathbf{n}_{t-1}\right)
$$

where $F_{t} 18$ the expected number of entrants in $t$ and $P_{t}$ is the cholce probability of entry at $t$. Similarly, the expected number of gross exits 18:

$$
Y_{t}=Q_{t} \times n_{t-1}
$$

where $Y_{t}$ is the expected number of gross exits, $Q_{t}$ is the probability of exit at time $t$, and $n_{t-1}$, the number of existing firms, represents the population from which exteing firms are drawn. Combining equations (1) and (2), we have:

$$
E_{t}=P_{t} \times\left(\bar{N}-n_{t-1}\right)+Q_{t} \times n_{t-1}+u_{t}
$$

where $E_{t}$ 1s the actual net entry in $t$ and $u_{t}$ is a random number obeylng the usual asumptions of regression. 1

Our next task 18 to specify the variables on which the probability of entry and exit $\left(P_{t}\right.$ and $\left.Q_{t}\right)$ depend and to Indicate an approprlate and measurable proxy variable for $\overline{\mathrm{n}}$, the population of potential entrants. In general terw, we have already noted that $P_{t}$ depende upon disequilibrla between supply and demand, upon the percelved risks of entry, and on the attributes (mainly production and marketing costs) of existing firms and of the population of potential entrants. We now turn to a more concrete specification of these variables.

$1_{u_{t}}$ appears in the equation since $E_{t}$ is the observed actual rather than the unfbserved expected net entry. 
A correct measure of the magnitude of transitory disequilibrium is the difference between actual price, $p_{a}$ and equilibrium, $p_{e}$. In the absence of such Information, we assume that this difference is a function of the growth rate in demand and, hence, output, per f1rm. That 1s:

$$
p_{a, t-1}-p_{e, t-1}-f\left((\hat{q} / n)_{t-1}\right)
$$

there the previously undefined symbol $(\hat{q} / n)$ is the growthrate in output per firm, $q / \dot{h}$, measured by $\frac{(q / n) t_{t}-(q / n) t-1}{(q / n){ }_{t-1}}$. The assumed funct fonal relation stems partly/ the gestat lon perlod In creating new capacity and partly from dynamic adjustment costs. The latter lead to diseconomles with high growth and such diseconomles are assumed to be an Increasing function of the growth rate. ${ }^{1}$ As a result, with a high growth rate per firm, prices can be expected to rise, thus ralsing the expected rate of return to entry.

We turn now to rlsk. We cannot, of course, measure all the forces that Influence risk. However, for a given objective probability distribution of rates of return to investment in a new product market, the percelved rlak to a potential entrant 1s a function of how many other firms made ouccessful Investaints in the wame market. We characterize this as the "dewongtration effect" and asume it to be a function of $n_{t-1}$, the number of existing firme in the market.

If we essume that entry (or diffusion in use) depends exclusively on the demonstration effect, $n_{t-1}$, and the population of potential entrants (or users), $\bar{N}$, a familiar model of diffusion emerges. First, consider the case where $\alpha(t)$,

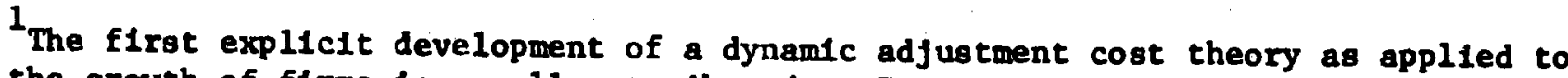
the growth of firms is usually attributed to $\mathrm{E}$. Penrose, The Theory of the Growth of the F1rm, Oxford, Basil Blackwe1l, 1959.
} 
the probab1lity of entry per small interval of $t$ ime, and $B(t)$, the probability of exit for the same small 1nterval, are both constant and $\alpha(t)>\beta(t)$. It can be shown that:

$$
n_{t}=\frac{\alpha \cdot \bar{N}}{\alpha+\beta}+\left(n_{0}-\frac{\alpha \bar{N}}{\alpha+\beta}\right) e^{-(\alpha+\beta) t}
$$

where the only previously undefined symbols $18 \eta_{0}$, the Initial number of firms In the market. It 18 clear from the above that the growth path for $n$ (the number of flrms in the maxket) is exponential with an asymptotic maximum at $\alpha \bar{N} /(\alpha+\beta)$. Now consider the case where $\beta(t)$ is agaln a constant or zero, but $\alpha(t)$ is subject to the demonstration effect and, therefore, changes over time so that $\alpha(t)=a_{t}$. We then have the following differential equation:

$$
\dot{n}_{t}=a_{t}\left(\bar{N}-n_{t}\right)-B n_{t}
$$

where $\dot{n}_{t}$ 1s the expected net entry per small 1nterval of time, or:

$$
\dot{n}_{t}=a^{\star n_{t}}\left(1-n_{t} / \bar{N}\right)-B n_{t}
$$

where $a^{*}=\operatorname{axd}$. It 18 clear from the above that if $a^{*}>\beta$, we have a logist 1c growth path for $n$ with an asymptotic maximum of $\bar{N}\left(1-\beta / a^{\star}\right)$.

The above model, with a demonotration effect and a fixed number of potential wers (or entrants), 1s precisely the model Implied in Grillches sentnal art1cle on the diffusion of hybrid corn. ${ }^{1}$ Our theoretical framework differs in that $B(t)$ 10 not aseused to be constant and $\alpha(t)$ depends critically on variables other than the demonetration effect and the number of potent1al users or entrants.

12. Grilichee, "Hybrid Corn: An Exploration In the Economics of Technological Chenge," Econometr1ca, October 1957. A similar though more complex model was subsequently presented in B. Mansfield, "Technolog1cal Change and the Rate of Imitat1on," Econometrica, October 1961. 
We have now specifled the demonstration effect as controlling perceptions of rlsk and we have specifled our proxy for transitory disequilibrium. Next, consider the attributes of existing firms in the market and of the population of potential entrants. As a simplification, and in the absence of contrary information, we assume that both sets of firms are drawn from a common universe except wth respect to one class of attributes. Existing firms will have accumulated over the period they have been in the market a stock of knowledge and expertence, of human capital that 18 not rapidly reproducible, and of goodwill in the market. Consequently, they have an advantage over new entrants which is an Increasing function of the accumulated volume of past production (and sales). We approximate the effect of such accumulated experience by $\Sigma q_{t-1} / \Sigma q_{T}$ where $\Sigma q_{t-1}$ is the accumulated aggregate output from the inftal introduction of the product to $t-1$. It 18 deflated by $\Sigma q_{T}$, the accumulated aggregate output to the end of the Interval covered by our data to permit the use of pooled cross-section as well as time-series data.

The effect of accumulated experience w111, ceter 18 par1bus, stead11y Increase over time unt1l it becomes a prohibltive barrier to entry for most firms. However the faster the rate of technical change in production processes or products, the 1 ess is the relevance of past experience for the future, and the higher the technical change in products the smaller 18 the effect of accumulated goodwill. A proxy for technical change should therefore have a positive 8 ign In our model. To conclude the discussion of gross entry, we specify that the population of potential entrants, $\bar{N}, 18$ proportional to the number of firms in the host Industry of the product innovation. Implicit in this is the assumption there are technological and marketing linkages among product markets in the same Industry. It further assumes the size of the population of firms technically equipped to enter an Industry (though not already in 1t) is related to the number of firms 
In the Industry. Obvlously these assumptions are viewed only as approxtmations to reality. How good such approximations are is an empirical question as 18 our compromise with theory in defining the boundaries of Industries in accordance with the 4-digit SIC classification.

Turning now to $Q_{t}$, the probability of exit, we must once again, in the context of 11mited Information, start with simplifying assumptions. Specifically, we start with the premlse that exlsting firms have valid engineering forecasts of their costs, and that the priaclpal surprises and disappointments leading to exct result from errors in forecasting prices and market demand (or output). Obviously, there will be 1nstances of exit arising from unlque historical circumstances such as the retirement of an owner-manager, or the inability of some f1rms to produce a product that appeals to end users. But how Important these special circumstances are 18 an emplrical question to be tested Indirectly by the adequacy of the general variables es explanations of the relevant phenonenon.

To test our hypotheses on exit, we employed a method first developed by Solow. 1 lanely, we constructed a number of hypothetical serles of expected output and price by the wodel of adaptive expectations. The model specifies that $x_{t+1}^{e}=x_{t}^{e}+\lambda\left(x_{t}-x_{t}^{e}\right)$ where $x_{t}^{e}$ and $x_{t}$ are, reapectively, the expected and the actual values of the varlable under consideration at $t$ lme $t$, and $\lambda$ to the opeed of adfustment with values between zero and one. For a given $\lambda$, a time series of the expected output and price can be conetructed by 1teration, otarting with a olngle Inttial value and using the observed tiwe serles of output and price as elements. We created hypothetical time seriee of the expected output and price for $\lambda=0.1,0.5$ and 0.9 , representing a slow, moderate, and fast adjustment process.

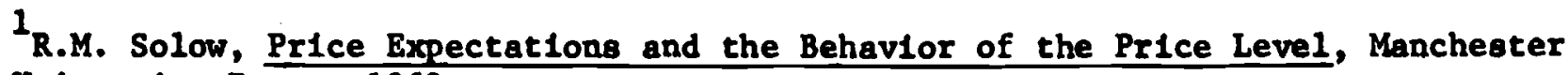
Untversity Press, 1969.
} 
Assuming that the expected and actual values are the same at some imitial point In time, a time series of error rates in expectations can be generated, $\left(x_{t}-x_{t}^{e}\right) / x_{t}, t-1,2, \ldots, T$, based on the differences between the actuel and expected values.

Using the time series of error rates in expectations of output and price, we took two-year averages of the error rates in expectations as well as the annual estimates. Th1s was done partly because of the arbitrariness of a oneyear interval in assessing the effects of disappointments and surprises on extt declsions, but partly also to differentlate between immediate (short-run) and lagged (long-rum) effects. Accordingly we used $q_{t}^{*}$ for output (or $p_{t}^{*}$ for price) and $\bar{q}_{t-1}$ for output (or $\bar{p}_{t-1}$ for $p r i c e$ ) in our equation where $q_{t}^{*}$ (or $p_{t}^{\star}$ ) is the current year error rate in expectations of output (or price) and $\bar{q}_{t-1}=\frac{q_{t-1}^{*}+q_{t-2}^{*}}{2}$. $\left(\operatorname{or} \bar{p}_{t-1}=\frac{p_{t-1}^{*}+p_{t-2}^{*}}{2}\right)$

Before turning to empirical tests, a review of some of the economic lssues ralsed by our model may be helpful. Flrst, can a general model devold of the unique Institutional aspects of each product market explain the observed phenomenon? For example, we have said nothing about the role of a small number of critical patents as entry barriers even though patents are commonly believed to have had a role in some of the product markets with whlch we dealt. Second, though diseconomies of scale have often been proposed by economiats as explanation for entry instead of faster growth by exlating firms, we have excluded this varlable from our model. Since the average alze of firm normally continues to grow long after net entry approacheo zero, diseconomles of scale are viable explanations of the hlotory of diffusion in production only if spectal assumptions are made about shifts over time in the minimum and maximum efficient size of firms. Such assumptions tend to be ad hoc and are difficult to fit into a general model. 
A third basic 1ssue 1s our assumption that there is a definable and measurable population of potentlal entrants as distinct from the universe of business firms. And finally, there 1s the question of the power of several varlables, in terms of their effect on entry. In particular, what is the Influence of the demonstration effect, of accumulated experience and goodwill, and of dynamic adjustment costs?

\section{Estimation Procedure}

The estimating procedure that was appropriate differed from ordinary least squares because of the need to Impose Inequality constraints on the parameters. Since the probability of entry or of exit cannot be less than zero or greater than 1, and since OLS estimates do not guarantee parameters that fall within these 11mits, a constralnt needs to be 1mposed. The 1mposition of constralnts, as the section on statistical results will show, considerably improved our results in terms of consistency of estimates with theory.

We may spectfy our model for $E_{t}$, actual net entry, as follows:

$$
E_{t}=\sum_{j=1} w_{f t} \theta_{j}+u_{t}, \quad t=1,2, \ldots, T
$$

where

$$
w_{j t}= \begin{cases}x_{j t} \times\left(\bar{N}-\eta_{t-1}\right), & j=1,2, \ldots, \ell \\ -x_{f t} \times \eta_{t-1} & j=\ell+1, \ldots, 8\end{cases}
$$

and $x_{j t}(j=1,2, \ldots, l) 18$ an explanatory variable of the probability of entry at t1me $t$ or $p_{t} \cdot x_{j t}(j-\ell+1, \ldots, s)$ 1s an explanatory varlable of the probab1lity of exit at time $t$, or $Q_{t} \cdot O_{j}$ '- are parametere aasocieted with the explanatory variablea, $x_{j}{ }^{\prime} 8$.

We may write our linear Inequality constraints in the form

$$
\begin{aligned}
& 0 \leq \sum_{1=1}^{l} w_{f t}{ }^{\theta} \leq\left(\bar{N}-n_{t-1}\right) \\
& -n_{t-1} \leq \sum_{\ell+1}^{s} w_{f t} \theta_{f} \leq 0 \quad \quad t=1,2, \ldots, T
\end{aligned}
$$


We assume that the error term $u_{t}$ satisfies the usual Gauss-Markov conditions. The above procedure can be formulated as a quadratic programing problem and solved by a finite computational routine such as the Lemke algorithm. The resulting est1mates of $\theta$ will be asymptotically unblased, consistent, and efficient, provided the specification is correct. 1

Data

The sample of product Innovations was selected from a set of forty-six product histories developed in connection with a related research project. ${ }^{2}$ of the forty-81x, only $s 1 x$ had data on output, prices, number of firms, and patents, over the entire period necessary for our analysis. Our method of analysis Involves the pooling of cross-section and time-series data so that complete, or almost complete, histories were essential.

Information on number of firms was obtalned from Thomas' Reglster of American Manufactures, supplemented by correspondence with Industry experts and by a varlety of other trade sources. Annual data on the number of patents lssued for each product were obtalned from the United States Patent Office. Date on prices and output were derived from a varlety of government and private sources, Including trade publications and Information provided by companies in the relevant product markets. Counts of product and process 1mprovements subsequent to the Initial Introduction of each of the $81 x$ products were also derived from a wide varlety of published and unpublished sources, Including product historles provided by Individual companies. $\bar{N}$ was based on data from the Census of Manufactures for $1947,1954,1958$, and 1963.

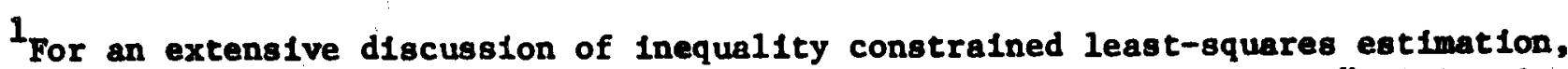
see Chong KIew LIew, "Inequality Constrained Least-Square Estimation", Journal of the American Stat1stical Assoclation, September 1976.

${ }^{2}$ see M. Gort and S. Klepper, op. c1t. 
As previously noted, the period chosen for each of the six products, encompassed the interval from take-off in entry or the time when the complete date became avallable to the time when the number of firms in the market reached 1ts historical peak. The products and relevant time intervals are 11sted below.

1. DDT, $1944-52$ (9 years)

2. Streptoryctn, 1946-53 (8 years)

3. Styrean, 1955-65 (1I years)

4. Televilon recelvers, 1946-55 (10 year8)

5. Trans18tors, 1954-61 (8 years)

6. Cathode ray tubes, 1948-1959 (12 year8)

\section{Resulte}

Table 1 sumarises the principal statistcal results. The equation tested whth, however, variations in the inclueion of Belected varlables. (see Table 1), was:

$$
\begin{aligned}
B_{t} & =\left[\alpha_{0}+\alpha_{1} n_{t-1}+\alpha_{2}(\dot{q} / a)_{t-1}+\alpha_{3}\left(\Sigma q_{t-1} / \Sigma q_{T}\right)+\alpha_{4} \nabla_{t-1}+\alpha_{5} w_{t-1}\right]_{x}\left(\overline{\mathbb{N}}_{t-1}-n_{t-1}\right) \\
& -\left[\left(\beta_{0}+\beta_{1} \bar{q}_{t}^{++\beta_{2}} q_{t-1}+\beta_{3} \bar{p}_{t}^{*+\beta_{4}} p_{t-1}\right) \times n_{t-1}\right]+u_{t-1}
\end{aligned}
$$

where

$$
\begin{aligned}
& E_{t} \text { - net entry } \\
& n_{t-1}=\text { number of existing firms in } t-1 \\
& \Sigma q_{t-1} / \Sigma q_{T} \text { - accumulated output to } t-1 \text { divided by the accumulated } \\
& \text { output at the end of the period studies } \\
& v_{t-1} \text { - the number of patents losued in } t-1 \\
& w_{t-1} \text { - the number of product and production process Improvements } \\
& \text { recorded in } t-1 \\
& q_{t}^{*} \text { - the rate of expectation error in output per firm in time } t \\
& \left.\frac{(q / n)_{t}-(q / n)_{t}^{e}}{(q / n)_{t}}\right)
\end{aligned}
$$


Table 1

Regression Coefficients, t-statistics, and correlations for explanations of net entry 1

\begin{tabular}{|c|c|c|c|c|c|c|c|c|}
\hline & OLS $^{2}$ & ICLS $^{3}$ & $\mathrm{OLS}^{2}$ & ICLS $^{3}$ & $\mathrm{OLS}^{2}$ & ICLS $^{3}$ & $\mathrm{OLS}^{2}$ & ICLS $^{3}$ \\
\hline $\boldsymbol{\alpha}_{0}$ & $\begin{array}{r}0.0321 \\
(3.374)\end{array}$ & $\begin{array}{r}0.0276 \\
(3.306)\end{array}$ & $\begin{array}{r}0.0275 \\
(2.801)\end{array}$ & $\begin{array}{r}0.0268 \\
(3.231)\end{array}$ & $\begin{array}{l}0 . \\
(3 .\end{array}$ & $\begin{array}{r}0.0321 \\
(2.957)\end{array}$ & $\begin{array}{c}0.0328 \\
(2.794)\end{array}$ & $\begin{array}{r}0.0312 \\
(2.894)\end{array}$ \\
\hline$\alpha_{1}$ & $\begin{array}{r}0.0005 \\
(2.311)\end{array}$ & $\begin{array}{c}0.0008 \\
(6.155)\end{array}$ & $\begin{array}{r}0.0005 \\
(2.471)\end{array}$ & $\begin{array}{r}0.0008 \\
(6.547)\end{array}$ & $\begin{array}{r}0.0004 \\
(1.968)\end{array}$ & $\begin{array}{r}0.0008 \\
(6.070)\end{array}$ & $\begin{array}{r}0.0004 \\
(2.161)\end{array}$ & $\begin{array}{c}0.0008 \\
(6.466)\end{array}$ \\
\hline$a_{2}$ & $\begin{array}{r}-0.0061 \\
(-1.673)\end{array}$ & $\begin{array}{l}-0.0056 \\
(-1.754)\end{array}$ & $\begin{array}{r}-0.0054 \\
(-1.463)\end{array}$ & $\begin{array}{l}-0 \\
(-1\end{array}$ & $\begin{array}{r}-0.0047 \\
(-1.239)\end{array}$ & $\begin{array}{l}-0.0050 \\
(-1.896)\end{array}$ & $\begin{array}{r}-0.0039 \\
(-1.001)\end{array}$ & $\begin{array}{l}-0.0049 \\
(-1.880)\end{array}$ \\
\hline$a_{2}$ & $\begin{array}{l}-0.0518 \\
(-2.731)\end{array}$ & $\begin{array}{l}-0.0411 \\
(-4.021)\end{array}$ & $\begin{array}{r}-0.0474 \\
(-2.499)\end{array}$ & $\begin{array}{l}-0 \\
(-3\end{array}$ & $\begin{array}{l}-0.0 \\
(-2.4\end{array}$ & $\begin{array}{r}-0.0499 \\
(-4.718)\end{array}$ & $\stackrel{-0}{(-2}$ & $\begin{array}{l}-0.0492 \\
(-4.771)\end{array}$ \\
\hline a & - & - & -- & - & $\begin{array}{c}0.0001 \\
(0.1007)\end{array}$ & $\begin{array}{c}0.0001 \\
(0.1511)\end{array}$ & $\begin{array}{c}0.0002 \\
(0.2105)\end{array}$ & $\begin{array}{c}0.0001 \\
(0.1633)\end{array}$ \\
\hline & - & $\cdots$ & - & - & $\begin{array}{l}-0.0035 \\
(-1.275)\end{array}$ & $\begin{array}{l}-0.0025 \\
(-1.222)\end{array}$ & $\begin{array}{l}-0.0035 \\
(-1.242)\end{array}$ & $\begin{array}{l}-0.0025 \\
(-1.233)\end{array}$ \\
\hline$B_{0}$ & $\begin{array}{c}-0.0222 \\
(-0.3754)\end{array}$ & $\begin{array}{r}0.0943 \\
(4.474)\end{array}$ & $\begin{array}{c}0.0328 \\
(0.4764)\end{array}$ & $\begin{array}{c}0.1040 \\
(4.710)\end{array}$ & $\begin{array}{c}-0.0372 \\
(-0.6130)\end{array}$ & $\begin{array}{r}0.0905 \\
(4.358)\end{array}$ & $\begin{array}{c}0.0210 \\
(0.2993)\end{array}$ & $\begin{array}{r}0.1001 \\
(4.589)\end{array}$ \\
\hline$B_{1}$ & - & - & $\begin{array}{l}-0.0104 \\
(-0.1550)\end{array}$ & $\begin{array}{c}0.0084 \\
(1.630)\end{array}$ & - & - & $\begin{array}{l}019 \\
269)\end{array}$ & $\begin{array}{r}0.0080 \\
(1.579)\end{array}$ \\
\hline$B_{2}$ & $\begin{array}{r}-0.1964 \\
(-3.847)\end{array}$ & $\begin{array}{l}-0.1238 \\
(-3.766)\end{array}$ & $\begin{array}{l}-0.1836 \\
(-3.497)\end{array}$ & $\begin{array}{l}-0.1331 \\
(-4.122)\end{array}$ & $\begin{array}{l}-0.1978 \\
(-3.838)\end{array}$ & $\begin{array}{l}-0.1192 \\
(-3.622)\end{array}$ & $\begin{array}{l}-0.1866 \\
(-3.492)\end{array}$ & $\begin{array}{l}-0.1283 \\
(-3.970)\end{array}$ \\
\hline B & -- & -- & $\begin{array}{r}0.3048 \\
(1.644)\end{array}$ & $\begin{array}{c}0.0778 \\
(4.672)\end{array}$ & & & $\begin{array}{r}0.3096 \\
(1.662)\end{array}$ & $\begin{array}{r}0.0749 \\
(4.569)\end{array}$ \\
\hline$B_{4}$ & $\begin{array}{l}-0.8638 \\
(-2.487)\end{array}$ & $\begin{array}{l}-0.9269 \\
(-2.468)\end{array}$ & $\begin{array}{r}-0.5966 \\
(-1.439)\end{array}$ & $\begin{array}{l}-0.9113 \\
(-2.533)\end{array}$ & $\begin{array}{l}-0.7911 \\
(-2.030)\end{array}$ & $\begin{array}{l}-0.8808 \\
(-2.397)\end{array}$ & $\begin{array}{r}-0.5197 \\
(-1.237)\end{array}$ & $\begin{array}{r}-0.8734 \\
(-2.475)\end{array}$ \\
\hline & & 0.7548 & & 0.7637 & & 0.7608 & & 0.7697 \\
\hline$A$ & & 0.7214 & & 0.7187 & & 0.7152 & & 0.7121 \\
\hline
\end{tabular}

The symbols are identified in the text in the discussion of equation (10). $t-$ statistics are shown 1n parentheses. A dash olgnifles that the varlables was excluded In the specific version of the equation. The speed of adjustment coefficlents $\lambda$, wae .5 for expected output and .9 for expected price. $\hat{\mathrm{k}}^{2}$ is the correlation adfusted for degrees of freedom.

${ }^{2}$ Ordinary least squares egtimation.

${ }^{3}$ Inequality constrained least squares estimation. 
$\bar{q}_{t-1}$ - the average rate of expectation error in output in $t-2$ and $t-1$ $p_{t}^{*}$ - the rate of expectation error in price in time $t\left(\frac{p_{t}-p_{t}^{e}}{p_{t}}\right)$ $\bar{P}_{t-1}$ - the average rate of expectation error in price in $t-2$ and $t-1$ $\bar{N}_{t-1}=$ the population of potential entrants in $t$ ime $t-1^{1}$

Table 1 shows that our hypotheses with respect to the role of the denonstration effect (the coefficient $\left.\alpha_{1}\right)$ and the accumulated experience and goodwill $\left(\alpha_{2}\right)$ are etrongly confirmed as judged both by the signs of the coefficients and the $t$ statiotic. The elaeticitiee measured at the means, and averaged for the $81 x$ products $^{2}$ are quite high. A one percent Increase in the variable that measures the demonstration effect leads to a 1.87 percent increase in entry. A one percent Increase in the variable that measures accumulated experience leads to a 2.88 percent decresse in entry.

Our ascumption that the population of potential entrants can be roughly approxinated by $\bar{n}_{t-1}$, whare $\overline{\mathrm{N}}_{t-1}$ lo peseured by the number of firns in the bost Induatry, is also strongly confirmed. An alternative apecification in which the s1se of the population of potentlal entrants was asoumed to equal $2 \bar{\pi}_{t-1}-n_{t-1}$ reduced $R^{2}$ aterially.

Our reoults Indicate also that $n_{t-1}$ affectively measures the population of potential exits. It appears unnecessary to diatinguish between earlier and Iater entrants-thit is, to devise a measure that takes account of the extent to which $n_{t-1}$ consiste of recent or of old entrante-in wesuring potential

${ }^{1}$ Any point in time preceding a census year was given the value of the observation for the prevlous census year. .

${ }^{2}$ Since the absolute values of the relevant vartat $16 \vdots . j-y$ acrose the six products, the elasticities vary accordingly. 
gross exit. Disappointments in output and in price expectations came through as strong explanatory varlables and with the correct signs for the lagged varlables. Our best results were with a moderate speed of adjustment coefficlent, $\lambda=.5$, for errors in output expectations and a much faster adjustment, $\lambda=.9$, for errors in price expectations. The reversal of signs on current and lagged errors In expectations 18, a prior1, plaus1ble. Greater expected than realized values reflect optimlem and, In the short run, should not lead to exit. It takes time for disappointments to take their effect on decisions to leave the market.

Among the negative results, dynamic adfustment costs leading to disequilibria-:at least to the extent that this variable can be measured by the growth rate in output per firm--did not have a statistically gignificant effect on entry. Ne1ther did the proxies for rate of technical change. In the case of the annual volume of patenting, the deficlency is in the cholce of proxy. The number of patents does not capture technological change for two reasons: first, important patents are not diatingulshed from trivlal ones and, second, it is in any event an Index of the Input of Innovative effort rather than of the output of Innovations. We employed th1s proxy only because it has been widely used in economlc 11terature (we belleve, Incorrectly) as an Index of technical change. Our second Index of technical change, the number of product and production process improvements falled to contribute to explaining the phenomenon perhaps because the information 18 too thin to be uged in the context of a model teated agalnat annual date. Too many of the annual observations were zeros. 1

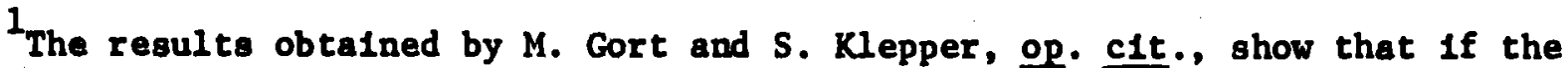
entry h1story 18 decomposed Into stages each consisting of a number of years, the frequency of product and production process lnnovations is much higher during pariode of high than of low entry.
} 
The positive results appear to be quite robust in the sense that minor changes in elther the 118t of variables (as Indicated in Table 1) or the cholce of a lag (to conserve space, results using alternative lags are not shown) do not markedly change th. $\alpha^{\prime} s$ and $\beta^{\prime} s$. Simflarly, the use of alternative speed of adjustent coefficlents for expectation errors, while it reduces the ${ }^{2}$, does wot, In wost Instances, change the signs or the statist1cal significance of the key variables. In contrast, if inequality constrained least equares 18 substituted by ordinary least squares estimation--a procedure we have Indicated 1s Inapproprlate--the results are materially affected.

Finally, a question might be ralsed whether, becauge of unidentified structural changes, net entry declines simply as the time approaches the point at which the number of producers is at a historical peak. Using $T$ as the gymol for that polnt, we added $T-t$ to the $118 \mathrm{t}$ of varlables in the model specified by equation (10). The additionsl varlable contributed nothing to explaining net entry and, in fact, $R^{2}$ adjusted for degrees of freedom declined. Conclustons

The empirical results confirm that a simple model-simple in terms of number of variables--1s sufficlent to explain wost of the phenomenon of diffusion In the production of an Innovation. The principal variable that explains diffusion of entry is the demongtration effect. The principal variable that retards entyy and finally brings it to an end 18 the accumulated experience and goodw111 of existing firms, operating a a barrier to entry. A limiting force 1. the population of potential entrants approximated by the number of firms in the host Industry of a product Innovation (m1nus, of course, the number that have already entered). None of these varlables appears to lend itself readily to influence by public palicy. 
Our study begins with the point in time correoponding to entry by the first competitors of the initial innovators. The first stage-the interval from first comerctal Introduction of the product to entry by competitorsvaries greatly in duration. It may well be that institutional variables, Including public pollcy, have a greater impact on the length of this first stage than on the diffusion process in the periods examined in this paper. 
References

(1) Chong Klew Llew, "Inequality Constralned Least-Square Estimation," Journal of the American Statiotical Assoclation, September 1976.

(2) M. Gort and S. Klepper, "Time Paths In the Diffusion of Product Innovations," State UnIversity of New York at Buffalo, Economics Department, D1scussion Paper No. 444.

(3) 2. Griliches, "Hybrid Corn: An Explolation in the Economics of Technological Change," Econometrica, October 1957.

(4) B. Mansfleld, "Technological Change and the Rate of Imitation," Econometrica, October 1961.

(5) E. Penrose, The Theory of the Growth of the F1rm, Oxford, Bas11 Blaclarell, 1959.

(6) R.M. Solow, Price Expectations and the Behavior of the Price Level, Manchester University Pres8, 1969. 